\title{
PENINGKATAN KOMITMEN PROFESI GURU MELALUI PENGEMBANGAN KEPRIBADIAN DAN PEMBERDAYAAN
}

\author{
Irma Fitriyanti ${ }^{1}$, Soewarto Hardhienata ${ }^{2}$, Hari Muharam ${ }^{2}$ \\ ${ }^{1}$ Guru SDN Batutulis 2 Kota Bogor, Jawa Barat \\ ${ }^{2}$ Program Pascasarjana Universitas Pakuan, \\ Email: pasca@unpak.ac.id
}

\begin{abstract}
This research was conducted using correlation statistical methods to determine whether other variables, namely personality development and teacher empowerment, have a positive relationship with the teacher's commitment to the profession. Based on these results, the analysis is carried out using the Sitorem Method to make recommendations and determine the priority sequence of improvements that need to be made. The study was conducted at Elementary School Honor Teachers in South Bogor District, Bogor City with a population of 173 teachers and a sample of 121 teachers. The results showed that there was a positive relationship between personality development and teacher commitment to the profession with the strength of the relationship $r_{y 1}=0.686$ and there was a positive relationship between teacher empowerment and teacher commitment to the profession with the strength of relationship $r_{y 2}=0.651$. This shows that the teacher's commitment to the profession can be improved through the development of personality and from the empowerment component of the teacher itself. The results of the Sitorem Analysis show that the components of personality development, teacher empowerment and teacher commitment to the profession find 6 welldefined and maintained indicators, namely: 1) Awareness, 2) Anxiety, 3) Teacher Guidance, 4) Feeling involvement, 5) Career drive, and 6) Acceptance of organizational value. While the components that need to be improved are 10 components in the order of improvement of priorities as follows: 1) Compliance, 2) Openness, 3) Hospitality, 4) Improving teacher capacity, 5) Motivation and support, 6) Provision of facilities, 7) Cooperation, 8) Confidence in the profession, 9) Obligations to the profession, 10) Calculation of the cost of transfer / professional effects.
\end{abstract}

Keywords: Teacher's Commitment to the Profession, Personality Development, Teacher Empowerment, Sitorem Analysis

\begin{abstract}
ABSTRAK
Penelitian ini dilakukan dengan menggunakan metode statistik korelasi untuk menentukan apakah variabel lain, yaitu pengembangan kepribadian dan pemberdayaan guru, memiliki hubungan positif dengan komitmen guru terhadap profesi. Berdasarkan hasil ini, analisis dilakukan menggunakan Metode Sitorem untuk membuat rekomendasi dan menentukan
\end{abstract}


urutan prioritas perbaikan yang perlu dibuat. Penelitian dilakukan pada Guru Honor Sekolah Dasar di Kecamatan Bogor Selatan, Kota Bogor dengan populasi penelitian 173 guru dan sampel 121 guru. Hasil penelitian menunjukkan bahwa ada hubungan positif antara pengembangan kepribadian dan komitmen guru terhadap profesi dengan kekuatan hubungan $\mathrm{r}_{\mathrm{y} 1}=0,686$ dan ada hubungan positif antara pemberdayaan guru dan komitmen guru dengan profesi dengan kekuatan hubungan $r_{\mathrm{y} 2}=0,651$. Ini menunjukkan bahwa komitmen guru terhadap profesi dapat ditingkatkan melalui pengembangan kepribadian dan dari komponen pemberdayaan guru itu sendiri. Hasil Analisis Sitorem menunjukkan bahwa komponen pengembangan kepribadian, pemberdayaan guru dan komitmen guru untuk profesi menemukan 6 indikator yang terdefinisi dengan baik dan dipertahankan yaitu: 1) Kesadaran, 2) Kecemasan, 3) Pembimbingan Guru, 4) Keterlibatan perasaan, 5) Dorongan berkarir, dan 6) Penerimaan nilai organisasi . Sementara komponen yang perlu ditingkatkan adalah 10 komponen dalam urutan perbaikan prioritas sebagai berikut: 1) Kepatuhan, 2) Keterbukaan, 3) Keramahan, 4) Peningkatan kemampuan guru, 5) Pemotivasian dan dukungan, 6) Penyediaan fasilitas, 7) Kerjasama, 8) Keyakinan pada profesi, 9) Kewajiban terhadap profesi, 10) Perhitungan biaya alih/efek profesi.

Kata Kunci: Komitmen Guru Terhadap profesi, Pengembangan Keprbadian, Pemberdayaan Guru, Analisis Sitorem. .

\section{PENDAHULUAN}

Salah satu dimensi guru yang diduga berkontribusi terhadap rendahnya kualitas pendidikan di Indonesia adalah komitmen profesi guru itu sendiri dalam menjalankan tugasnya. Rendahnya kualitas pendidikan di Indonesia pastinya tidak berdiri sendiri tetapi berkaitan atau dipengaruhi oleh kondisi seluruh komponen pendidikan secara sistemik, yaitu diantaranya kualitas dan pemerataan penyebaran guru, kurikulum, sumber belajar, sarana dan prasarana, iklim pembelajaran, serta sejauh mana political will pemerintah, baik di pusat maupun di daerah.

Dari semuanya itu, guru merupakan komponen paling menentukan, karena ditangan gurulah kurikulum, sumber belajar, prasarana dan sarana, serta iklim pembelajaran menjadi sesuatu yang berarti bagi kehidupan peserta didik. Figur satu ini akan senantiasa menjadi sorotan strategis ketika berbicara masalah pendidikan, karena guru selalu terkait dengan komponen manapun dalam sistem pendidikan.

\section{Komitmen Guru terhadap Profesi}

Menurut Goswarmi, Mathew dan Chadha (2007: 13-27) bahwa komitmen terhadap profesi sebagai hubungan psikologis antara individu dan pekerjaannya yang didasarkan pada reaksi afektif terhadap kerja. Cohen (2007: 1-30) menerangkan komitmen terhadap profesi didasarkan pada konsep profesionalisme, yaitu sejauh mana anggota individu mengidentifikasi dengan profesinya dan mendukung nilai-nilainya. Menurut Bargaim (2003: 353) mendefinisikan komitmen terhadap profesi sebagai keyakinan seseorang dalam penerimaan nilai-nilai atau pekerjaan yang dipilih atau garis kerja, dan kemauan untuk mempertahankan keanggotaan dalam pekerjaannya.

Restuningdiah (2009: 252) menerangkan bahwa komitmen terhadap profesi adalah keyakinan terhadap penerimaan tujuan dan nilai profesi dan bersedia memelihara 
keanggotaan. Sedangkan menurut Trisnaningsih (2002: 202) menjelaskan komitmen terhadap profesi adalah tingkat loyalitas individu pada profesinya yang dipersepsikan oleh individu itu. Individu dengan komitmen terhadap profesi tinggi akan menunjukan loyalitas pada pekerjaannya.

Berdasarkan teori-teori di atas dapat disintesiskan bahwa komitmen guru terhadap profesi adalah keyakinan seseorang dalam penerimaan nilai profesi, kemauan untuk mengerahkan usaha atas nama profesi serta bersedia bertahan dalam keanggotaan profesinya,

\section{Kepribadian}

Menurut Robbin dan Judge (2013: 167-173) kepribadian adalah keseluruhan cara dimana seorang individu bereaksi dan berinteraksi dengan individu lain. Sejalan dengan pendapat Ivancevich, et.al (2008: 72-75) bahwa kepribadian adalah perasaan perilaku yang relatif stabil yang dipengaruhi faktor turunan/genetik dan lingkungan. Kinicki dan Williams (2008: 360) mendifinisikan kepribadian adalah sebagai kombinasi dari karakteristik fisik dan mental yang stabil yang memberikan identitas pribadinya. Kepribadian terdiri dari sifat-sifat psikologis yang stabil dan atribut perilaku yang memberikan seseorang identitas dirinya.

Menurut Greenberg dan Baron (2008: 142-143) kepribadian merupakan pola yang unik dan relatif stabil dari perilaku, pikiran dan emosi yang ditunjukan oleh individu. Hellriegel dan Slocum (2011: 70-77) beerpendapat bahwa kepribadian mewakili profil keseluruhan atau kombinasi atribut psikologis yang stabil yang meerupakan sifat unik dari seseorang. Janasz, et.al. (2009: 8-9) kepribadian adalah menggambarkan karakteristik yang relatif stabil, kecenderungan dan temperamen yang telah dibentuk oleh faktor keturunan, sosial, budaya dan lingkungan.

Berdasarkan teori-teori di atas dapat disimpulkan bahwa kepribadian guru adalah perilaku seorang guru yang berkaitan dengan kemampuan individu dalam mewujudkan dirinya sebagai pribadi yang mandiri untuk melaksanakan tranformasi diri, identias diri, dan pemahaman diri dan memiliki nilai-nilai luhur sehingga terpancar dalam perilaku sehari-hari.

\section{Pemberdayaan guru}

Menurut Syafarudin (2002: 66) pemberdayaan berarti memberikan pegawai suatu pekerjaan untuk dilakukan dan kebebasan bagi mereka untuk melakukannya secara kreatif. Khoo Kheng Hor (2008: 42) alih bahasa oleh Drs. Untung Yowono menyatakan pemberdayaan adalah menciptakan keseimbangan antara karyawan sehingga tercipta kontrol ketika diperlukan, dan mempercayai karyawan untuk sanggup bekerja lebih baik.

Mulyasa (2005: 31) mengungkapkan pemberdayaan sebagai peningkatan pemahaman manusia untuk meningkatkan kedudukannya di masyarakat. Makmur (2008: 51) mendefinisikan pemberdayaan sebagai konsep atau usaha menumbuhkan keinginan seseorang untuk mengaktualisasikan diri, melakukan mobilitas ke atas serta memberikan pengalaman psikologis yang membuat seseorang berdaya. Sedangkan Griffin (2002: 54). Pemberdayaan adalah proses melibatkan pekerja untuk menetapkan tujuan-tujuan kerja mereka sendiri, membuat keputusan dan memecahkan masalah di dalam batas-batas tanggungjawab dan wewenang mereka.

Berdasarkan kajian-kanjian teori di atas dapat disintesiskan yang dimaksud pemberdayaan guru adalah pemberian kesempatan dan dorongan kepada para guru untuk mengaktualisasikan potensi, keterampilan dan bakat untuk mencapai tujuan yang ditetapkan sekolah, dengan indikator: 1) peningkatan kemampuan guru, 2) penyediaan fasilitas, 3) kerjasama, 4) Pembimbingan guru, 5) pemotivasian dan dukungan 


\section{METODE PENELITIAN}

Penelitian ini menggunakan pendekatan kuantitatif dengan metode survey untuk mengetahui sejauh mana pengembangan kepribadian dan pemberdayaan guru dapat meningkatkan komitmen guru terhadap profesi. Populasi dalam penelitian ini adalah guru honor Sekolah Dasar Negeri Sekecamatan Bogor Selatan berjumlah 173 guru dengan sampel ditentukan dari populasi secara acak berjumlah 121 guru. Untuk mendapatkan hasil yang optimal dalam upaya meningkatkan komitmen guru terhadap profesi menggunakan Metode Sitorem oleh Hardhienata (2017).

\section{HASIL PENELITIAN}

\section{Pengujian persyaratan analisis}

\section{Uji Normalitas}

Hasil perhitungan uji normalitas galat baku taksiran $\left(\mathrm{Y}-\hat{\mathrm{Y}}_{1}\right)$ variabel komitmen guru terhadap profesi $(\mathrm{Y})$ atas variabel pengembangan kepribadian $\left(\mathrm{X}_{1}\right)$ diperoleh nilai $\mathrm{L}_{\mathrm{hitung}}$ sebesar 0,078 sedangkan nilai $\mathrm{L}_{\text {tabel }}$ pada taraf signifikansi 0,05 dan $\mathrm{n}=121$ sebesar 0,081 . Persyaratan normal adalah $\mathrm{L}_{\text {hitung }}<\mathrm{L}_{\text {tabel }}$ dengan demikian galat baku taksiran $\left(\mathrm{Y}-\hat{\mathrm{Y}}_{1}\right)$ variabel komitmen guru terhadap profesi $(\mathrm{Y})$ atas variabel pengembangan kepribadian $\left(\mathrm{X}_{1}\right)$ memiliki data yang berdistribusi normal.

Hasil perhitungan uji normalitas galat baku taksiran $\left(\mathrm{Y}-\hat{\mathrm{Y}}_{2}\right)$ variabel komitmen guru terhadap profesi $(\mathrm{Y})$ atas variabel pemberdayaan guru $\left(\mathrm{X}_{2}\right)$ diperoleh nilai $\mathrm{L}_{\text {nitung }}$ sebesar 0,080 sedangkan nilai $\mathrm{L}_{\text {abee }}$ pada taraf signifikansi 0,05 dan $n=121$ sebesar 0,081 . Persyaratan normal adalah $\mathrm{L}_{\text {nitung }}<\mathrm{L}_{\text {abel }}$ dengan demikian galat baku taksiran $\left(\mathrm{Y}-\hat{\mathrm{Y}}_{2}\right)$ variabel komitmen guru terhadap profesi $(\mathrm{Y})$ atas variabel pemberdayaan guru $\left(\mathrm{X}_{2}\right)$ memiliki data yang berdistribusi normal.

\section{Uji homogenitas}

Pengujian homogenitas varians dilakukan dengan menggunakan uji Bartlett. Persyaratan data homogen adalah apabila nilai $\chi^{2}$ hitung lebih kecil dari $\chi_{\text {tabel pada taraf }}^{2}$ signifikansi $5 \%$. Dari hasil perhitungan uji homogenitas variabel komitmen guru terhadap profesi atas variabel pengembangan kepribadian diperoleh nilai $\chi^{2}$ hitung sebesar 44,21 sedangkan $\chi_{\text {tabel }}^{2}$ pada taraf signifikansi $5 \%$ dan $\mathrm{dk}=35$ sebesar 49,80. Karena $\chi^{2}$ hitung $<\chi_{\text {tabel, }}^{2}$, dengan demikian dapat disimpulkan bahwa kelompok data komitmen guru terhadap profesi atas variabel pengembangan kepribadian berasal dari populasi yang homogen.

Pengujian homogenitas dilakukan dengan menggunakan uji Bartlett. Berdasarkan hasil pengujian diperoleh nilai $\chi_{\text {hitung }}=60,47$ sedangkan $\chi_{\text {tabel }}^{2}=62,83$ dengan galat $5 \%$ dan derajat kebebasan 46. Persyaratan data tersebut homogen jika $\chi_{\text {hitung }}<\chi_{\text {tabel. }}^{2}$ Dengan demikian, kelompok skor data komitmen guru terhadap profesi $(\mathrm{Y})$ atas pemberdayaan guru $\left(\mathrm{X}_{2}\right)$ berasal dari populasi yang homogen $\left(\chi_{\text {hitung }}=60,47<62,83=\chi_{\text {tabel }}\right)$.

\section{Pengujian hipotesis}

\section{Hubungan antara pengembangan kepribadian (X1) dengan Komitmen guru terhadap profesi $(Y)$}

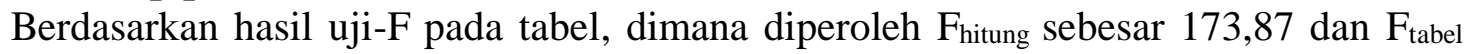
sebesar 3,92 $(\mathrm{dk}$ pembilang $=1$; dk penyebut $=119 ; \alpha=0,05)$ serta $F_{\text {tabel }}$ sebesar $6,85(\mathrm{dk}$ pembilang $=1$; dk penyebut $=119 ; \alpha=0,01$ ). Karena $F_{\text {hitung }}$ lebih besar dari $F_{\text {tabel }}$ pada taraf signifikansi baik $\alpha=0,05$ maupun $\alpha=0,01$, maka dapat disimpulkan bahwa koefisien korelasi $r_{\mathrm{y} 1}$ sangat signifikan.

Berdasarkan hasil analisis regresi sederhana, diperoleh konstanta regresi atau a $=$ 37,331 dan koefisien regresi atau $b=0,768$. Dengan demikian model hubungan fungsional antara pengembangan kepribadian dengan komitmen guru terhadap profesi dapat dinyatakan 
dalam regresi linear sederhana $\hat{Y}=37,331+0,768 X_{1}$. Uji linearitas dengan uji $F$ dilakukan untuk menguji apakah persamaan regresi tersebut linear atau tidak. Persamaan regresi dikatakan linear jika $F_{\text {hitung }}<F_{\text {tabel. }}$.

\section{Hubungan antara pemberdayaan guru ( $\left.\mathrm{X}_{2}\right)$ dengan Variabel Komitmen guru terhadap profesi (Y)}

Berdasarkan hasil uji-F pada tabel, dimana diperoleh $F_{\text {hitung }}$ sebesar 305,04 dan $F_{\text {tabel }}$ sebesar 3,92 $(\mathrm{dk}$ pembilang $=1$; dk penyebut $=119 ; \alpha=0,05)$ serta $F_{\text {tabel }}$ sebesar $6,85(\mathrm{dk}$ pembilang $=1 ; \mathrm{dk}$ penyebut $=119 ; \alpha=0,01)$. Karena $\mathrm{F}_{\text {hitung }}$ lebih besar dari $\mathrm{F}_{\text {tabel }}$ pada taraf signifikansi baik $\alpha=0,05$ maupun $\alpha=0,01$, maka dapat disimpulkan bahwa koefisien korelasi $\mathrm{r}_{\mathrm{y} 2}$ sangat signifikan.

Berdasarkan hasil analisis regresi sederhana, diperoleh konstanta regresi atau $\mathrm{a}=$ 65,594 dan koefisien regresi atau $b=0,572$. Dengan demikian model hubungan antara pemberdayaan guru dengan komitmen guru terhadap profesi dapat dinyatakan dalam regresi linear sederhana $\hat{Y}=65,594+0,572 X_{2}$. Uji linearitas dengan uji $F$ dilakukan untuk menguji apakah persamaan regresi tersebut linear atau tidak. Persamaan regresi dikatakan linear jika $F_{\text {hitung }}<F_{\text {tabel }}$.

\section{Hubungan antara pengembangan kepribadian $\left(\mathrm{X}_{1}\right)$ dan pemberdayaan guru $\left(\mathrm{X}_{2}\right)$ secara bersama-sama dengan Komitmen guru terhadap profesi (Y).}

Berdasarkan hasil uji $\mathrm{F}$ pada tabel ANAVA, dapat dilihat nila $\mathrm{F}_{\text {hitung }}$ sebesar 63,01 sedangkan $\mathrm{F}_{\text {tabel }}$ dengan dk pembilang $=2$ dan dk penyebut $=118$ pada taraf signifikansi $\alpha=$ 0,05 sebesar 3,07 dan taraf signifikansi $\alpha=0,01$ sebesar 4,79. Dapat disimpulkan bahwa nilai $F_{\text {hitung }}>F_{\text {tabel}}$, hal ini menunjukkan bahwa persamaan regresi $\hat{Y}=36,640+0,506 X_{1}+0,279 X_{2}$ dapat dipergunakan untuk memprediksi tingkat komitmen guru terhadap profesi melalui pengembangan kepribadian dan pemberdayaan guru.

Selain itu, berdasarkan hasil perhitungan uji-t diperoleh nilai $t_{\text {hitung }}$ sebesar 11,23 dan nilai $t_{\text {tabel }}$ pada galat $5 \%$ sebesar 1,98 dan pada galat $1 \%$ sebesar 2,62. Karena $t_{\text {hitung }}>t_{\text {tabel }}$, maka koefisien korelasi antara pengembangan kepribadian dan pemberdayaan guru secara bersama-sama dengan komitmen guru terhadap profesi sangat signifikan.

\section{Korelasi parsial}

Berdasarkan hasil perhitungan uji korelasi parsial yang pertama diperoleh nilai korelasi parsial antara pengembangan kepribadian (X1) dengan komitmen guru terhadap profesi (Y) dimana pemberdayaan guru (X2) dikontrol (ry12) $=0,414$.

Berdasarkan hasil uji signifikansi, nilai tersebut sangat signifikansi karena thitung lebih besar dari ttabel. Dengan demikian, dapat disimpulkan bahwa terdapat hubungan positif yang sangat signifikan antara pengembangan kepribadian dengan komitmen guru terhadap profesi dimana variabel pemberdayaan guru dikontrol.

\section{PEMBAHASAN}

\section{Hubungan Antara pengembangan kepribadian (X1) dengan Komitmen guru terhadap profesi (Y)}

Terdapat hubungan yang positif antara pengembangan kepribadian dengan komitmen guru terhadap profesi. Hal ini dapat dilihat pada hubungan fungsional antara pengembangan kepribadian dengan komitmen guru terhadap profesi yang ditunjukkan oleh persamaan regresi $\hat{Y}=37,331+0,768 X 1$ artinya setiap kenaikan satu skor pengembangan kepribadian dapat meningkatkan skor komitmen guru terhadap profesi sebesar 0,768 pada konstanta 37,331 . 
Hasil penelitian tersebut sejalan dengan hasil penelitian Raisah Surbakti (2011: 51) dengan judul Pengaruh Motivasi, Kepribadian dan Kepuasan Kerja Terhadap Komitmen Guru MAN 2 Padangsidimmpuan. Dari hasil perhitungan data bahwa kepribadian memiliki pengaruh yang positif dan bermakna terhadap komitmen guru pada sekolah sebesar $37 \%$.

Berdasarkan uraian di atas maka pengembangan kepribadian merupakan salah satu faktor penentu dalam meningkatkan komitmen guru terhadap profesi.

\section{Hubungan Antara pemberdayaan guru (X2) dengan Variabel Komitmen guru terhadap profesi (Y)}

Terdapat hubungan yang positif antara pemberdayaan guru dengan komitmen guru terhadap profesi. Hal ini dapat dilihat pada hubungan fungsional antara pemberdayaan guru dengan komitmen guru terhadap profesi yang ditunjukkan oleh persamaan regresi $\hat{\mathrm{Y}}=65,594+0,572 \mathrm{X}_{2}$ artinya setiap kenaikan satu skor pemberdayaan guru dapat meningkatkan skor komitmen guru terhadap profesi sebesar 0,572 pada konstanta 65,594.

Hubungan positif antara pemberdayaan dengan komitmen terhadap profesi diperkuat dengan hasil penelitian dari artikel yang berjudul Optimization of Enhancement of Lecturer Proffesional Committment Using Path Analisys and Sitorem Method oleh Sri Setyaningsih, Muhamad Saad Nurul Ishlah, dan Soewarto Hardhienata, (2016:22) menunjukkan bahwa terdapat hubungan positif dan signifikan antara pemberdayaan dengan komitmen profesional . Dengan koefisien korelasi sebesar $=0,92$ dan $($ sig $<0,05)$. Analisis dan koefisien determinasi $\rho y 1=0,34$ ini menunjukkan pemberdayaan memberikan kontribusi sebesar $34 \%$ terhadap komitmen profesional.

Berdasarkan uraian di atas maka pemberdayaan guru merupakan salah satu faktor penentu dalam meningkatkan komitmen guru terhadap profesi.

\section{Hubungan antara variabel pengembangan kepribadian ( $\left.\mathrm{X}_{1}\right)$, variabel pemberdayaan guru ( $\left.\mathrm{X}_{2}\right)$ Secara Bersama-sama dengan Komitmen guru terhadap profesi (Y)}

Hubungan secara bersama-sama antara variabel pengembangan kepribadian dan pemberdayaan guru dengan komitmen guru terhadap profesi, memiliki koefisien korelasi sebesar ry12 $=0,719$ dan koefisien determinasi r2y12 $=0,516$ sehingga dapat disimpulkan bahwa 51,6\% komitmen guru terhadap profesi dapat ditingkatkan melalui variabel pengembangan kepribadian dan pemberdayaan guru secara bersama-sama. Hal ini menujukkan makna bahwa menurut penilaian responden, kedua faktor pengembangan kepribadian dan pemberdayaan guru secara bersama-sama ternyata memberikan sumbangan yang sangat signifikan bagi peningkatan komitmen guru terhadap profesi.

Hasil penelitian diperkuat oleh hasil penelitian journal Bogler and Somech (2004:23) dengan judul Influence of Teacher Empowerment on Teachers' Organizational Commitment, Professional Commitment and Organizational Citizenship Behavior in Schools menunjukkan bahwa self-efficacy dengan status (M1/42:94;s.d.=0.72) menunjukkan pengembangan kepribadian atau efikasi diri memberikan kontribusi sampai $72 \%$ terhadap komitmen profesi serta dimensi temuan paling banyak tentang pemberdayaan guru di antara guru sekolah menengah dengan status $\left(\mathrm{M}^{1 / 44} / 14\right.$; s.d.=0.51) ini menunjukkan pemberdayaan memberikan kontribusi sampai dengan $51 \%$ terhadap komitmen profesi.. Temuan-temuan ini menyiratkan bahwa guru memiliki peluang untuk menumbuhkan keprofesionalan diri, efektif di pekerjaan serta berkepribadian baik.

Berdasarkan uraian di atas, maka pengembangan kepribadian dan pemberdayaan guru merupakan faktor penentu dalam meningkatkan komitmen guru terhadap profesi. 
Berdasarkan penilaian dari pakar (expert judgment) dan analisis dari peneliti, maka dapat disusun bobot urutan prioritas indikator-indikator yang perlu dengan segera diperbaiki dan yang perlu dipertahankan dan dikembangkan seperti gambar rekapitulasi hasil akhir analisis SITOREM berikut ini.
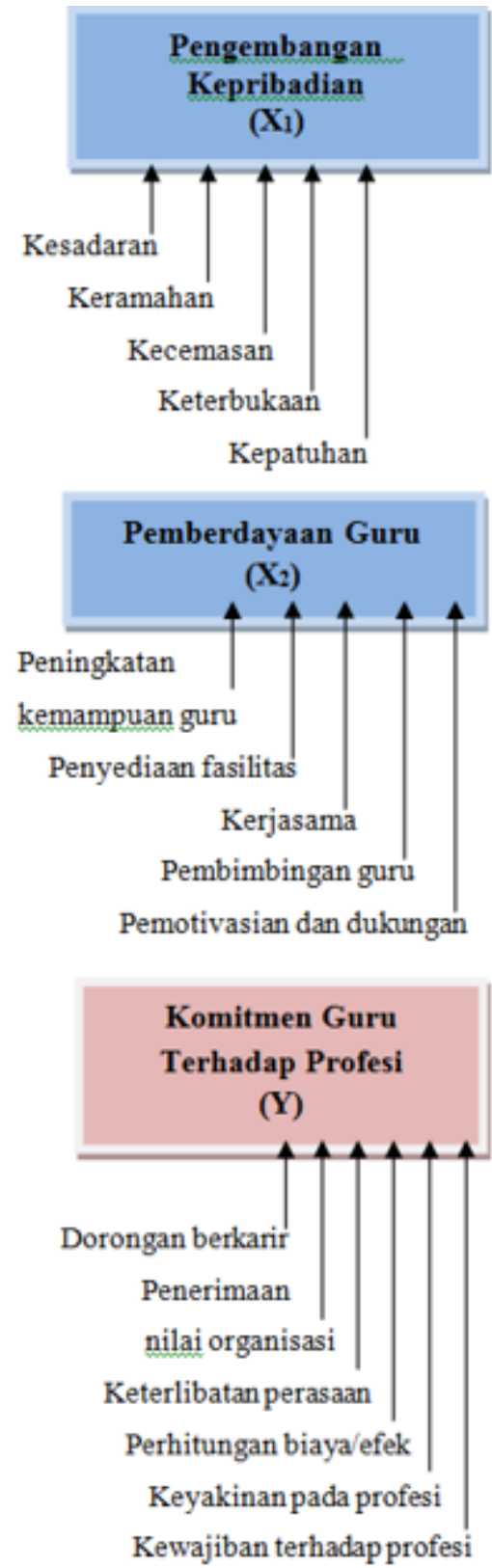

$\mathrm{r}_{\mathrm{y} 1}=0,686$

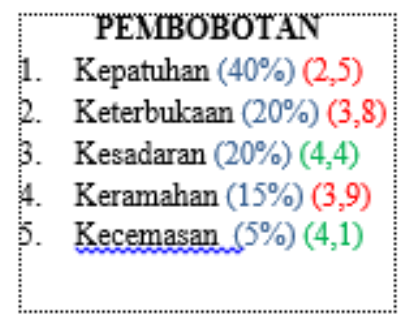

$\mathrm{r}_{\mathrm{y} 2}=0,651$

\section{PEMBOBOTAN}

1. Peninghatan kemampuan $\operatorname{gun}(35 \%)(3,3)$

2. Pembimbing an gưu $(25 \%)(4,5)$

3. Pemotivasian dan dukungan $(20 \%)(3,9)$

4. Penye diaan fasilitas $(15 \%)(3,5)$

5. Kerjasama $(5 \%)(3,8)$

\section{PEMBOBOTAY}

1. Keyakinan pada profesi $(30 \%)(3.9)$

2. Kewajiban terhadap profesi $(25 \%)(3,3)$

3. Perhitungan biaya/efek $(15 \%)(3.9)$

4. Keterlibatan perasaan $(15 \%)(4,1)$

5. Dorongan berkarir $(10 \%)(4.5)$

6. Penerimaan nilai organisasi $(5 \%)(4.1)$
1. Kepatuhan

2. Keterbukaan

3. Keramahan

4. Peningkatan kemampuan guru

5. Pemotivasian dan dukungan

6. Penyediaan fasilitas

7. Kerjasama

8. Keyakinan pada profesi

9. Kewajiban terhadap profesi

10. Perhitungan biaya/efek

\begin{tabular}{|l|}
\multicolumn{1}{c|}{ URUTAN } \\
INDIKATOR \\
DIPERTAHANKAN \\
1. \\
2. Kesadaran \\
Kecemasan \\
4. \\
Pembimbingan Guru \\
Keterlibatan perasaan \\
Dorongan berkarir \\
Penerimaan nilai \\
organisasi
\end{tabular}

Gambar 8. Hasil Analisis Sitorem

\section{SIMPULAN}

Berdasarkan analisis terhadap data hasil penelitian dapat disimpulkan terdapat hubungan positif sangat signifikan antara pengembangan kepribadian dengan Komitmen guru terhadap profesi, antara pemberdayaan guru dengan Komitmen guru terhadap profesi dan antara pengembangan kepribadian dan pemberdayaan guru bersama-sama dengan Komitmen guru terhadap profesi. Berdasarkan hasil penelitian ini maka untuk meningkatkan Komitmen guru terhadap profesi dapat dilakukan dengan meningkatkan pengembangan kepribadian dan perbaikan pada pemberdayaan guru. 


\section{DAFTAR PUSTAKA}

Bagraim, JJ. 2003. Impact of Affective Organizational and occupational Commitment on Job Satisfaction: PR Specialist in Metropolitan Municipalities. International Journal of Business and Commerce. Volume 2 No. 2:21-35.

Cohen Aaron, 2007. Dynamics between Occupational and Organizational Commitment in the Context of Flexible Market, Institut Technik und Bildung (ITB), Universitat Bremen. Volume 26: 1-30.

Goswarmi, Mary Mathew \& Chadha. 2007. Differences in Occupational Commitment amongst Scientists in Indian Defence, Academic, and Commercial R\&D Organizations. Vikalpa Journal. Volume 32 No. 4: 13-27.

Greenberg Jerrard dan Robbert A. Baron , Behavior in Organizations (New Jersey: PearsonEducation Inc., 2008), Pp. 142-143.

Hardhienata, S., 2017. The Development of Scientific Identification Theory to Conduct Operation Research in Education Management. IOP Conference Series: Materials Science anad Engineering. Volume 166, 2017.

Hellriegel dan Slocum, Organizational Behavior, $13^{\text {th }}$ Edition (South-Western: Chengage Learning, 2011), pp. 70-77.

Kinicki Angelo dan Brian K. Williams, Management a Pratical Introduction (New York: McGraw-Hill, 2008), Pp. 360.

Kreitner Robert dan Kinicki Angelo, Organizational Behavior, (New York: McGraw-Hill, 2008), p. 133.

McShane Steven L, Organizational Behavior (New York: McGraw Hill, 2010), pp. 38-43.

Nurika Restuningdiah. 2009. Pengaruh Komitmen terhadap Profesi terhadap Kepuasan Kerja Akuntan Pendidik melalui Komitmen Organisasional. Jurnal Ekonomi Bisnis. Volume 14 No. 3:252.

Surbakti, R. "Pengaruh Motivasi, Kepibadian, dan Kepuasan Kerja terhadap Komitmen Guru MAN 2 Padangsimpuan”,Desertasi, Universitas Negeri Medan, 2011.

Syarif Makmur, Pemberdayaan Sumber Daya Manusia dan Efektivitas Organisasi, (Jakarta: Raja Grafindo, 2008).,p.51 Ibid.,p.52.

Tri Trisnaningsih. 2002. Pengaruh Komitmen terhadap Kepuasan Kerja Auditor: Motivasi sebagai Variabel Intervening. Studi Empiris pada Kantor Akuntan Publik di Jawa Timur. Jurnal Riset Akuntansi Indonesia. Volume 6 No. 21:202. 